\title{
A look in the back yard: Mitigating home-grown extremism in Canada
}

\author{
Dean R. Young*
}

\begin{abstract}
Canada has the capability to provide a significant security blanket with which to protect Canadian citizens from the effects of terrorism. I will discuss the scholarly work in the area of extremism and associated ideologies. Contemporary issues of environmentalism, race and gender, and government legitimacy will be examined with respect to how they contribute to growing extremist segments of Canadian society. Findings support the argument that, as society grows in its liberal approaches, extreme ideologies from those on the fringes may begin to grow in order to counter the influence of opposing views and social policy. This article closes with a discussion of how the growth of extremism may be mitigated through attention to history and societal development, asserting control over the Internet, strengthening the criminal justice system, and education.
\end{abstract}

Key Words Homegrown terrorism; extremism; mitigation; conservatism; liberalism; social agents.

Journal of CSWB. 2020 April;5(1):15-18

www.journalcswb.ca

\section{INTRODUCTION}

Terrorism is not strictly an imported commodity. We generate our own culpability through homegrown social challenges that increase the potential for radicalization, through political developments (both traditional and contemporary), and as a result of growing global social problems that are transcending borders and cultures. The social conditions giving rise to extremism, both from the right and the left, are growing in Canada. While the current situation may not indicate an imminent revolution, it forms the very conditions that have created extreme social and political ideologies in the past (Public Safety Canada, 2018; Parent \& Ellis, 2016; Berger, 2016; Kohler, 2016; Crawford \& Pilanski, 2014; Levitas, 2002). As Canadian society continues to grow in its openness, and social and political activism grows to cross all boundaries and borders, managing information in terms of veracity and content continues to challenge our social institutions.

The federal government names terrorism and extremism as a major priority in Canada (Public Safety Canada, 2018). Canadian homegrown extremism must be considered a social problem at the very roots of society and we must empower Canadian society to address the matters that lead to the development of behaviours fuelled by dogma and extreme narratives. The increasing prevalence of blind faith in Internet commentators and social engineers, and the very little veracity of online narratives regarding volatile issues such as the rise in nationalism, immigration and refugees, ethnic pride, and environmentalism all potentially contribute to the increase in extremism or, at the very least, in the dissatisfaction of society and in fear of these issues. This article's focus will be on identifying the role grassroots social growth plays in the development of extremism, with the aim of mitigating the growth of terrorism.

\section{DOGMATIC ISSUES IN CANADIAN EXTREMISM}

According to Crawford and Pilanski (2014), both Liberals and Conservatives are motivated to afford more rights to groups and individuals with whom they agree. Equally, according to Sabbagh (2005), individuals "occupying different social positions favour different justice principles because these principles enhance a self-interested pattern of instrumental benefits" (p. 119). It stands to reason, however, that egalitarianism is very much a foundation for social and political life, in that power is a central theme in social and political dynamics. The pursuit of equality is simply a power struggle. I find Crawford and Pilanski's focus on intolerance to be another significant factor in the dissent between Liberal and Conservative ideologies with respect to the manner in which society manages ideological approaches to conflict. They focus on the determination of liberalism and conservatism as more of a valid perspective. According to Crawford and Pilanski:

both political liberalism and conservatism predict intolerance of politically opposing targets and that such 
intolerance is explained by perceived threat from these targets. Moreover, both liberals and conservatives were biased in their intolerance judgments, with conservatives expressing more intolerance of left-wing than comparable right-wing targets and liberals expressing more intolerance of right-wing than comparable left-wing targets. (2014, p. 847)

Their research advances that, with respect to political issues and the way political expression is undertaken, both Liberal and Conservative factions are intolerant of those with whom they disagree, and that intolerance was justified by how threatening those political opponents were perceived. As such partisanship continues to grow in the population, we could see a ripe breeding ground for an increase in Canadian extremism, both from the right and from the left.

Environmentalism and climate change is one of the most significant issues in contemporary global life and politics in the 21st century, and is becoming the basis of militancy and extreme behaviour. A contemporary example of this phenomenon can be seen in the recent North American tour by Greta Thunberg and the newest forms of neo-environmental narratives of the contemporary global climate change dialogue. The vitriolic behaviour on both sides that resulted from the visit made it clear that both the Conservative and Liberal ideological sides experienced perceived threats and believed important values each held were under attack. This perception of attack, from either side, further supports the idea that fear is growing, and the associated behaviours have the potential to enhance the growth of extreme thoughts and behaviours to the degree of radicalization and thus be the path to terrorist action, especially when local economic factors are considered. The climate change movement has solidly demonstrated the sheer emotionalism and interconnectedness between issues of economics and climate change. One of the most powerful worries for most is the fear for their ability to make a living. For example, Albertans felt threatened by Thunberg's environmental message, which went straight to the heart of the livelihoods of many Alberta residents. The strong emotions expressed by Thunberg, such as anger and frustration, elicited the very justification needed by the conservative population to grow and show the type of intolerance researched by Crawford and Pilanski. As climate change increases in relevance and, with it, social desperation, I would posit that the future will hold ever increasing measures taken by advocates. We have seen examples of extreme environmentalism in Canada, such as the Wiebo Ludwig conflict in the 1990s with the oil producers in Alberta. In 2013, Public Safety Canada considered eco-terrorism to be a leading domestic threat and that environmentalists could be a major hazard to the public (Yang, Su, \& Carson, 2014).

It is of interest that, in Public Safety Canada's 2018 report on terrorism in Canada, there is no mention of eco-terrorism in the assessment of contemporary terrorism threats. Parent \& Ellis (2016) posit that extremist groups are characterized by loose, heterogeneous groups and individuals that claim to believe in deep-seated grievances that typically include anti-government sentiments (involving individual sovereignty, anti-globalization/anti-immigration), racism, fascism, race supremacy (including white supremacy, anti-Semitism, and anti-Muslimism), misogyny-based values, and sexual-/ gender-based values. Further, they have found that rightwing extremists do not fall specifically into cohesive groups, as they can be religious or secularly organized, and there is frequently conflict from within these groups. I believe that these groups that espouse a broader, more general, condemnation of social and political issues can further fuel the others. Parent and Ellis open the door for this issue to be considered a single-issue extremist matter.

Research has shown a connection between dogmatism and rigid adherence to political intolerance (Levitas, 2002; Crawford \& Pilanski, 2014). With respect to right-wing ideology, white supremacy, anti-immigrant, and anti-Islamic sentiments have been given a forum, from both growth on the Internet and a growing liberalization of the ruling political power, to contribute to in mushrooming conflict between ethnic groups and those who are fearful of a multitude of perceived social ills. Public Safety Canada defines right-wing extremism as follows:

traditionally driven by hatred and fear, and includes a range of individuals, groups, often in online communities, that back a wide range of issues and grievances, including, but not limited to: anti-government and anti-law enforcement sentiment, advocacy of white nationalism and racial separation, anti-Semitism and Islamophobia, anti-immigration, male supremacy (misogyny) and homophobia. The threat of violence from any individuals, including those holding extreme right-wing views, may manifest in terrorist activity or other forms of criminal violence. However, while racism, bigotry, and misogyny may undermine the fabric of Canadian society, ultimately, they do not usually result in criminal behaviour or threats to national security. (2018, para. 25)

However, political/social extremism is growing in its violence, evidenced by groups such as the misogynist movement of involuntary celibates (Incels) and the anti-government sovereign citizens. According to Louie:

when a term like Incel is created and used in online forums, it allows all of these isolated and alienated people to unite and for once feel a sense of connection, acceptance, and understanding, which in turn allows them to share their sense of shame and self-condemnation. But it also allows for a perfect storm of not only self-hatred but vitriol, rage, and a desire to inflict harm on others whereby victims can also experience firsthand the grief and suffering that Incels feel they've had to endure for a lifetime. (2018, para. 12)

The Incel movement is described as, "by ideals of male supremacy, believing that men are the victims of oppressive feminism that has destroyed society and thwarted their perceived entitlement to women's bodies" (Dixon, Harkins, \& Wegerhoff, 2019, p. 681). By nature of the supremacy ideology, Incels fall within the category of extremism. The growth of this very specific movement may have resulted from the movement that saw the increase of women's rights from the 1960 s to the 1980s. The rise of the power afforded to women and the associated programs and policies to forward that 
goal is interpreted as a perceived removal of power from men. Widespread Internet communication between individuals about contemporary sexual politics can then bring those with grievances together to share information and to develop a sense that there are others with similar issues. Additionally, such communication allows for the dissemination of information, false or otherwise, that fuels the cause.

The Sovereign Citizen movement is yet another example of this backlash to a growing and changing society. This is an interesting movement, not only because it is identified as a terrorist group in the United States, but also because it shares both left- and right-wing ideologies. Although the Sovereign Citizen movement began in the United States, the dogmatic foundations remain the same in Canada. What is concerning about this movement is its dissemination of dogma over the Internet, spawning self-professed gurus who sell legal filing kits and guidelines (Berger, 2016). This use of the internet to spread ideology and to exploit the disenfranchised is similar to the spread of extreme thought, such as the previously discussed Incels. However, these tactics, when used by such self-professed gurus, are more akin to the radicalization tactics seen in Islamic extremism than in the Incel movement.

\section{GROWTH IMPLICATIONS}

Historically, the development of most, if not all, terrorist groups has roots in unbalanced power dynamics, typically socioeconomic and political power. Race and cultural differences, and the associated political implications, have played a significant role in the growth of extremist groups, such as the FLQ and militant indigenous groups, and more currently the growth of Islamic-inspired terrorism. In addition, contemporary liberal-leaning groups are beginning to gain social momentum, such as the gender-/sex-based movements (e.g., LGBTQ+ and Incels), as well as environmentalism and climate change. These historical and contemporary movements produce lessons, or the potential to foresee growing extremism. Society tends to forget the impact of significant events and usually has difficulty drawing lessons from the past once the movement has been quelled or is no longer popular. However, we can see the ebb and flow with respect to social movements, and history certainly demonstrates that past social conflicts continue to re-emerge, couched in contemporary issues.

Growing dissatisfaction with contemporary government continues to fuel both right- and left-wing extremism, and the growth of homegrown responses. Specific internal matters continue to erode faith in the capabilities of the government to keep Canadians safe from both internal and external threats. Global conflicts contribute to Canada's own challenges, such as increased race relations, refugeeism and immigration, as well as dissatisfaction with the way in which Canada's governments are dealing with economic downturn, and how the government is legislating social issues, touching on gender/ sexual roles, the environment, religion and spirituality.

Immigration has consistently increased in Canada (Statistics Canada, 2018). As a result, Canadian society has already seen an increase in race-related extreme ideological narratives, both generally with respect to closing borders to refugees and specifically with growing Islamophobic sentiments. If the research is accurate, Canada will continue to see social discord in terms of race and will also begin to see the displacement of racial tensions (and associated cultural and political tensions) from the homelands of new Canadians.

\section{MITIGATION}

Canada, both politically and socially, must continue to look to the past to counter the conditions that contribute to homegrown extremism. While the Canadian government works on mitigation of the growth of such groups through the development and exercise of legislation and the criminal justice system (Public Safety Canada, 2018), socialization agents must take a stronger role in education and addressing these conditions at a grassroots level in local communities: schools, religious institutions, local law enforcement, community social groups, and mental health institutions.

A significant mitigation must come from gaining appropriate control over the uncontrolled proliferation of information disseminated over the Internet. Public Safety Canada warns that, in Canada, those people who are inspired to extremism use low sophistication and low resource tactics to commit their violent activity and are still capable of delivering the high casualty- and publicity-generating events. The Internet can be considered a low sophistication tool, as it is an easily acquired tool and is simple to use to further such causes. Further, these groups typically use online resources for recruitment, facilitation, and guidance. As society becomes increasingly isolated and its knowledge base formed more by the Internet, we must strive to create stronger opportunities to combat the false narratives typical of the spread of extremist thought and ideology. The Internet is not, by design, a tool of evil. It can also be the saviour with respect to education, a mitigation yet to be discussed. It has become a significant wayfinder for information and communication, both protective factors with respect to countering all sorts of threats to society. The problem is that the internet became weaponized. As with any weapon, we must build a safety response before that tool can be rendered controllable. Regardless of the inherent lag with legislation, Canada continues to play catch up with public safety matters involving the Internet.

Legal and justice enforcement systems in Canada must continue to adjust to the rapid transformation of public safety as it is affected adversely by the growth of homegrown extremism. Although the Criminal Code of Canada and the criminal justice system have continued to lag behind technological advances in crime and communication for the purposes of criminal activity, there are successes in prosecutions for offences committed involving the matters covered in this article (Yang, Su, \& Carson, 2014; Public Safety Canada, 2018). However, the justice system remains bogged down in its own complexity, in civil libertarian disputes, and in constitutional arguments that prevent it from being a truly effective tool to counter growing extremism as it begins to transgress the law.

Granted, the Canadian justice system requires significant oversight to ensure the Charter of Rights and Freedoms is upheld, so that the system does not suffer disrepute; however, the system allows for the growth of hate-fuelled ideology due to its inability to address the matters contemporaneously and the fact that it operates at a speed that cannot keep pace with the sheer rapidity of the Internet. The current judicial system in Canada is also failing to counter the growing extremist 
movements, issuing correctional sentences that are not in line with the severity of the crime because ideological criminal behaviours are not considered serious offences. It is concerning that some of these contemporary movements are being judged as low-level threats when compared with issues such as Islamic terrorism; in reality, they are just in their infancies. The purpose of this article is to explore how we may intervene in the growth of such movements, rather than wait until they are on par with the larger-scale, more global, threat actors.

Education is the single most significant tool in mitigating the growth of extremism. Dogma is a natural state of human ideology and will always be present. When considering the definitions and the typologies provided in this article, what is common to most forms of extremism is ignorance. As such, in order to mitigate the growth of extremist ideology, it is vital to educate the upcoming generations and bolster their abilities in critical thinking to counter the false narratives and to combat racism and misogyny, as well as strengthening social legitimacy to combat intolerance. We must strive to lessen society's emotionalism with respect to issues of great importance, and to empower the next generations to seek social justice through legitimate knowledge. Knowledge is a powerful tool to address social justice and can be the redress to political barriers and social ignorance. Canadian society is rife with socialization agents, be they schools, religious institutions, youth and community groups, or parents. There can be no valid excuse as to why children cannot be better inculcated with the ability to think for themselves following healthy discourse and the ability to conduct independent research. The use of socialization agents to radicalize has been demonstrated as being very effective with respect to extreme ideologies. The same methods can be used by social institutions to buttress knowledge and veracity to reduce the proliferation of extreme ideologies.

\section{CONCLUSION}

In this article, I have explored the scholarly work in the area of extremism and associated ideologies. I set out to examine the potential for homegrown extremism in Canada with respect to the contemporary issues of environmentalism, race and gender, and government legitimacy. In exploring Canada's experience with movements such as environmentalism, sexual/gender motivation, self-sovereigns, I am convinced that the conditions exist that could contribute to a growing extremist segment of Canadian society. I would argue that we must expand resources that support education, as the most significant aspects of extremism are ignorance and intolerance. Canadian society continues to grow in its exercise of freedoms of expression, and social and political activism grows to cross all boundaries and borders, continuing to challenge our social institutions.

CONFLICT OF INTEREST DISCLOSURES

The author declares that there are no conflicts of interest.

AUTHOR AFFILIATIONS

*Wilfrid Laurier University, Waterloo, ON, Canada.

\section{REFERENCES}

Berger, J. (2016). Without prejudice: What sovereign citizens believe. Program on Extremism. George Washington University. Retrieved from https://extremism.gwu.edu/sites/g/files/zaxdzs2191/f/ downloads/JMB\%20Sovereign\%20Citizens.pdf

Crawford, J., \& Pilanski, J. (2014). Political intolerance, right and left. Political Psychology, 35(6), 841-851.

Dixon, L., Harkins, L., \& Wegerhoff, D. (2019). Incorporating sociocultural and situational factors into explanations of interpersonal violent crime. Psychology, Crime \& Law, 25(6), 675-692. Retrieved from https://journals-scholarsportal-info.libproxy.wlu.ca/pdf/1068316x/ v25i0006/675_isasfieoivc.xml

Koehler, D. (2016). Right-wing extremism and terrorism in Europe: Current developments and issues for the future. PRISM 6(2), 84-105

Levitas, D. (2002, July 22). The radical right after 9/11: The attacks hardened the resolve of immigrant bashers and anti-Semites. The Nation, 275(4), 19. Retrieved from https://link-gale-com.libproxy. wlu.ca/apps/doc/A88696750/AONE? $u=$ watel $8005 \&$ sid =AO NE\&xid $=c 9122 e 3 c$

Louie, S. (2018, April 25). The Incel movement: What are the sexual, social, recreational, and racial implications of Incels? Psychology Today. Retrieved from https://www.psychologytoday.com/ca/ blog/minority-report/201804/the-incel-movement

Parent, R., \& Ellis, J. (2016). The future of right-wing terrorism in Canada. The Canadian Network for Research on Terrorism, Security, and Society. Retrieved from https://www.tsas.ca/wp-content/ uploads/2018/03/TSASWP16-12_Parent-Ellis.pdf

Public Safety Canada. (2018). 2018 public report on the terrorist threat to Canada. Retrieved from https://www.publicsafety.gc.ca/cnt/ rsrcs/pblctns/pblc-rprt-trrrsm-thrt-cnd-2018/pblc-rprt-trrrsm-thrt-cnd2018-en.pdf

Sabbagh, C. (2005). Environmentalism, right-wing extremism, and social justice beliefs among East German adolescents. International Journal of Psychology, 40(2), 118-131.

Statistics Canada. (2018). 150 years of immigration in Canada. Retrieved from https://www150. statcan.gc.ca/n1/pub/11-630-x/11-630x2016006-eng.htm

Yang, S., Su, Y., \& Carson, J. (2014). Eco-terrorism and the corresponding legislative efforts to intervene and prevent future attacks. Canadian Network for Research on Terrorism, Security and Society. Retrieved from https://www.tsas.ca/publications/eco-terrorismand-the-corresponding-legislative-efforts-to-intervene-and-preventfuture-attacks/ 